\title{
Class E Basic Helix-Loop-Helix Protein 22
}

National Cancer Institute

\section{Source}

National Cancer Institute. Class E Basic Helix-Loop-Helix Protein 22. NCI Thesaurus. Code C79759.

Class E basic helix-loop-helix protein 22 (381 aa, $~ 37 \mathrm{kDa}$ ) is encoded by the human BHLHE22 gene. This protein is involved in the suppression of gene transcription. 